University of Wollongong

Research Online

Faculty of Business - Papers (Archive)

Faculty of Business and Law

$1-1-2015$

My lawfully wedded workplace: identifying relational similarities of marriage and employment

Irit Alony

University of Wollongong, ia120@uowmail.edu.au

Helen M. Hasan

University of Wollongong, hasan@uow.edu.au

Andrew J. Sense

University of Wollongong, asense@uow.edu.au

Michael L. Jones

University of Wollongong, mjones@uow.edu.au

Follow this and additional works at: https://ro.uow.edu.au/buspapers

Part of the Business Commons

Research Online is the open access institutional repository for the University of Wollongong. For further information contact the UOW Library: research-pubs@uow.edu.au 


\title{
My lawfully wedded workplace: identifying relational similarities of marriage and employment
}

\begin{abstract}
Purpose - The purpose of this paper is to introduce a novel direction of enquiry into predictions of employee turnover through the application of a qualitative method adapted from marital research. This method focuses on diagnosing the relationship, and has been able to predict divorce with an accuracy of over 90 per cent, as opposed to existing turnover prediction methods' modest success of about 30 per cent. By demonstrating that the method can be applied to turnover research, this study completes a seminal step in developing this promising direction of enquiry.

Design/methodology/approach - The Oral History Interview method for predicting divorce is adapted to employment settings, and tested on Australian legal and healthcare employees. A qualitative analysis of their responses maps the results from this inquiry onto separation-predicting processes identified in marital research. The results are compared to turnover data collected two years later.
\end{abstract}

Findings - Similar relational processes exist in marital and employment relationships when the marital relationship diagnostics method is applied to organisational settings, demonstrating the utility of this tool in the employment context. Preliminary turnover data indicate that some relational processes are significantly associated with employee turnover.

Research limitations/implications - Future research should examine the predictive power of this tool on a larger sample, and apply it to a wider range of professions, tenure, and positions.

Practical implications - The results indicate that it is viable to diagnose an employment relationship using this diagnostics method developed in marital research.

Social implications - The novel perspective offered in this paper has potential to greatly improve this employment relationship across jobs and organisations, thus improving organisational productivity and individual wellbeing.

Originality/value - Researchers of employee turnover and practitioners seeking to understand and manage it can benefit from this novel and practical perspective on employment.

\section{Keywords}

similarities, marriage, relational, employment, identifying, lawfully, workplace, my, wedded

\section{Disciplines}

Business

\section{Publication Details}

Alony, I., Hasan, H., Sense, A. \& Jones, M. (2015). My lawfully wedded workplace: identifying relational similarities of marriage and employment. Personnel Review, 44 (1), 140-160. 


\title{
My Lawfully Wedded Workplace: Identifying Relational Similarities of Marriage and Employment
}

\begin{abstract}
Purpose: This paper introduces a novel direction of enquiry into predictions of employee turnover through the application of a qualitative method adapted from marital research. This method focuses on diagnosing the relationship, and has been able to predict divorce with an accuracy of over 90\%, as opposed to existing turnover prediction methods' modest success of about 30\%. By demonstrating that the method can be applied to turnover research, this study completes a seminal step in developing this promising direction of enquiry.

Design/methodology/approach: The Oral History Interview method for predicting divorce is adapted to employment settings, and tested on Australian legal and healthcare employees. A qualitative analysis of their responses maps the results from this inquiry onto separationpredicting processes identified in marital research. The results are compared to turnover data collected 2 years later.
\end{abstract}

Findings: Similar relational processes exist in marital and employment relationships when the marital relationship diagnostics method is applied to organisational settings, demonstrating the utility of this tool in the employment context. Preliminary turnover data indicate that some relational processes are significantly associated with employee turnover.

Research limitations/implications: Future research should examine the predictive power of this tool on a larger sample, and apply it to a wider range of professions, tenure, and positions.

Practical implications: The results indicate that it is viable to diagnose an employment relationship using this diagnostics method developed in marital research. 
Social implications: The novel perspective offered in this paper has potential to greatly improve this employment relationship across jobs and organisations, thus improving organisational productivity and individual wellbeing.

Originality/value: Researchers of employee turnover and practitioners seeking to understand and manage it can benefit from this novel and practical perspective on employment.

Keywords: employee turnover, employment relationship, qualitative enquiry

\section{Introduction}

Regardless of the state of a nation's economy and other environmental drivers, employee turnover has been, and will remain, a problem of great concern to organisations (Lee \& Rwigema, 2005; Mowday, 1984; Weisberg \& Kirschenbaum, 1991). While reports of downsizing frequently make it into news headlines, this is not the problem from the perspective of the organisation; rather, it is voluntary turnover which creates the larger concern and which creates problems for businesses (Reiche, 2009; Yanadori \& Kato, 2007). This problem is associated with great costs and disruptions to optimum organisational function (Wöcke \& Heymann, 2012). Tangible economic costs associated with turnover have been estimated to range from US\$10,000 per employee (for about half the positions in the US) to over US\$100,000 per middle manager (Vaiman, 2008). In addition, intangible costs which include potential loss of valuable knowledge, skills, and organisational memory, remain a critical issue for contemporary organisations (Griffeth \& Hom, 2001). Tools which accurately predict employee turnover are valuable instruments which organisations can utilise to instigate changes which will prevent voluntary turnover, and minimise its associated impact. Predictive tools are therefore of great value to organisations (Benson, 2006; Brunetto, Teo, Shacklock, \& Farr-Wharton, 2012; Dysvik \& Kuvaas, 2010; Mano-Negrin \& 
Kirschenbaum, 1999). Companies which are able to predict turnover with a high level of certainty are able to leverage contingencies through the timely employment of replacement staff (Dess \& Jason, 2001), by cross-training of other staff (Fang, 2009; Knox \& Walsh, 2005), by establishing knowledge sharing processes (Jacobs \& Roodt, 2011), and adapting incentive systems to increase retention (Mowday, 1984).

This paper explores a novel relational approach to the prediction of staff turnover. It tests the viability of treating employment as a relationship between the employee and the organisation in a similar way as a marital relationship. The paper provides examples of the use of this approach in practice, and indications that the approach yields indicators which are similar in nature to those of a marital relationship. The paper is organised as follows: first, turnover literature is reviewed. This review discusses weaknesses in turnover prediction and then the new directions this field is pursuing. Then, a new method is introduced based on a current technique used to predict marital separation. Following this, the modified marital method is used to assess employees in Australian legal and healthcare organisations. The results of this assessment are presented next, followed by a discussion of their meaning to turnover research.

\section{Turnover literature}

Although scholars generally agree on the various factors that lead to voluntary turnover (Allen, Renn, Moffitt, \& Vardaman, 2007; Benson, 2006; Brunetto, et al., 2012; Loan-Clarke, Arnold, Coombs, Hartley, \& Bosley, 2010; Maertz, 2004), the current ability of these factors, combined or individually, to predict turnover is far from impressive. Considerable research describes the factors that push employees to voluntarily leave organisations (e.g. job dissatisfaction) (Khatri, Fern, \& Budhwar, 2001; McHugh, Kutney-Lee, Cimiotti, Sloane, \& Aiken, 2011; Milbourn, 2012), factors that pull employees away from organisations (e.g. alternative job opportunities) (Nyberg, 2010; Smith, Holtom, \& Mitchell, 2011; Swider, 
Boswell, \& Zimmerman, 2011), and the processes by which individuals make turnoverrelated decisions (Albion, Fogarty, Machin, \& Patrick, 2008; Griffeth, Hom, \& Gaertner, 2000; Morrell, Loan-Clarke, Arnold, \& Wilkinson, 2007). However, the ability to explain and predict individual voluntary turnover decisions remains limited. Most prediction methods rely on self-reported answers, and these return poor accuracy. For example, attitudes typically only explain around 5\% of turnover variance (Allen, et al., 2007; Griffeth, et al., 2000; Hom \& Griffeth, 1995). This creates issues of false positive and false negative results, meaning that a proportion of staff who are satisfied with their job will leave, while many who are dissatisfied will stay. Similarly, intentions to quit rarely explain more than $15 \%$ of the instances of turnover, which means that a majority of employees who report their intention to quit their job will not actually do so (Allen, et al., 2007; Griffeth, et al., 2000; Hom \& Griffeth, 1995). These limitations of existing prediction models indicate that no overarching theory of turnover provides a satisfactory explanation. This body of knowledge thus offers modest benefits, if any, to organisations.

The limited success with which these existing prediction models operate, despite vast and extensive research, suggests that perhaps this problem can be examined from a fundamentally different perspective. So far, turnover has been studied as if it was a decision which can be predicted mainly based on individual-centric and self-reported constructs (e.g., job satisfaction, organisational commitment, intentions to quit or stay, etc.) (Steel \& Lounsbury, 2009). However, the poor predictive accuracy of these methods indicates that this view of voluntary turnover is problematic, and may suffer from the various problems associated with self-reporting methods. For example: common method variance (Podsakoff, MacKenzie, Lee, \& Podsakoff, 2003), which occurs when the same method is used to measure different constructs, such as turnover intentions and job satisfaction, has been found to seriously bias results of relationships between constructs - about 25-30\% of the time (Doty \& Glick, 1998; 
Griffeth, et al., 2000; Podsakoff, et al., 2003; Steel \& Lounsbury, 2009; Winterton, 2004). Another problem is temporal restrictiveness: this means that attitudes are only measured at one point in time, when attitudes have been found to fluctuate considerably within the day (Sonnentag, 2003). Finally, self-presentation bias means that participants are more likely to respond by providing socially-desirable answers, rather than by truthful and authentic answers (Arnold, Feldman, \& Purbhoo, 1985; Carrère, Ruckstuhl, Buehlman, Gottman, \& Coan, 2000). These limitations of self-reporting methods prevent the attainment of a comprehensive understanding of the issue, as indicated from the lack of a comprehensive theory which successfully explains and predicts the process.

The impact of the quality of interpersonal relationships in the workplace on employee retention has drawn the attention of researchers to this aspect (Sias, Heath, Perry, Silva, \& Fix, 2004). Recently, turnover studies have begun to explicitly emphasise the effects of relational variables on turnover (e.g., Mossholder, Settoon, \& Henagan, 2005), and to examine turnover as a process of voluntary separation from the organisation (Winterton, 2004). The study reported on here seeks to further enhance the understanding of separation processes by drawing on this new body of research. A different type of voluntary separation that has been extensively studied is voluntary marital separation. Over the past few decades, substantial progress has been made on understanding the marital separation process (Gottman \& Notarius, 2002). While a thorough understanding of this related literature is beyond the scope of this paper, a meaningful appraisal of the accumulated knowledge in this field, as it relates to organisational turnover, is required. Key findings that are relevant to, and can be transferred into organisational turnover processes will be discussed in this paper, with a view to aiding the development of a model for predicting turnover that is more accurate than current models. The next section briefly explains the strong correlations between these two areas of research: marital separation research and organisational turnover. 


\section{Successfully predicting separation: methods from marital research}

Much like turnover, marital separation was initially studied using self-reported surveys. However, it was not until this research employed an interactional perspective that it began to see predictive empirical results. Marital research moved from a self-reported and personality-based approach to the study of interaction in the 1950s (Gottman \& Notarius, 2002). Following this shift, marital research used a multi-method approach and rapidly developed from the 1970s, as the interactional perspective required observational methods, rather than self-reported surveys. These methods integrated multi-faceted data, including interactional processes (e.g., reciprocity, criticism, and withdrawal), physiological indicators (e.g., heart-rate, perspiration, and body temperature), displays of affect, and self-report perceptual data, leading to a greater understanding of marital processes (Hicks, McWey, Benson, \& West, 2004).

One of these observational methods is particularly amenable to use in organisational context. This method has demonstrated a remarkable success at predicting divorce: with an accuracy of over $90 \%$, this widely-cited method has been reported to predict not only if a married couple will separate and divorce, but also when this separation will take place (i.e., within 7 or 14 years) (Gottman \& Notarius, 2000). When considering the modest success organisational turnover prediction models have had, such impressive prediction accuracy is, at the very least, intriguing.

The method relies on the Oral History Interview (OHI) for data collection. In this joint interview, the married couple are asked to describe significant events in the history of their marriage (i.e., the first date, the wedding planning, etc.). Researchers found that couples who emphasised more negative aspects in their reconstructed narratives were more likely to divorce, and this could be predicted with over $90 \%$ accuracy after a three year follow-up (Buehlman, Gottman, \& Katz, 1992). The analysis therefore focuses on identifying the ratio 
between positive and negative displays of affect between the married partners, during this joint interview.

This method for predicting marital separation is based on the fundamental assumption that a successful marriage is sustained by a balance between positive and negative interactions, in three different, but inter-related, domains: perceptual, behavioural, and physiological. An imbalance between positive and negative interactions between partners leads to marital distress, and eventually, to separation and divorce (Gottman, 1993, 1999). Predicting this trajectory towards divorce relies on the argument that memories are constructed based on what is cognitively salient (Fincham \& Bradbury, 1990), and that they are linked to experienced affect (Bradbury \& Fincham, 1987). Distressed couples have been shown to recall mostly negative events, whereas non-distresses couples are more likely to recount positive ones (Buehlman, Carrere, \& Siler, 2005). Similarly, it has been suggested that unhappy partners tend to overlook the positive behaviours of their spouse, for the same reason (Weiss, 1980). For example: a couple recalling their wedding day may emphasise the bad weather, or the wilting flowers - negative affect; or they underemphasise the bad weather, instead emphasising the more romantic mood - positive affect.

These notions of selective memory and biased spousal accounts were used to develop the Oral History Interview (OHI) method and, based on this, to successfully predict a couple's trajectory towards divorce (Buehlman, et al., 1992; Carrère, et al., 2000; Gottman, Coan, Carrere, \& Swanson, 1998).

The OHI enables to not only identify a ratio of negative-to-positive affective indicators in a couple's descriptions of their marital past. It also identifies several relational indicators in their conversation, which indicate marital distress or a lack thereof. Through analysis, several dimensions which predicted separation were identified in couples' recollections of 
their past (Buehlman, et al., 1992; Carrère, et al., 2000; Gottman, et al., 1998). These dimensions are summarised in Table 1.

Couples who scored low on fondness (dimension 1), we-ness (dimension 3), or expansiveness (dimension 4), or scored high on negativity (dimension 2), or disappointment (dimension 7) were quite accurately predicted (i.e., 94\%) to be divorced within a three-year follow-up. Couples who glorified the struggles in their relationship, or demonstrated positive patterns of behaviour (i.e., fondness, we-ness, etc.) were more likely to remain married.

\section{TABLE 1}

Dimensions of relational processes in marital research

1. Fondness/ Affection towards spouse

2. Negativity towards spouse

3. We-ness versus Separateness

4. Expansiveness versus withdrawal

5. Dealing with conflict
a. Volatility

b. Chaotic relationships

c. Glorifying the struggle

6. Marital disappointment and disillusionment
The extent to which the couple seemed to be in-love or fond of each other.

To what extent the spouse displays of negative affect towards each other during the interview, and how critical partners are towards each other during the interview. How much a spouse identifies with being part of a couple, versus emphasising their individuality or independence. How expressive and expansive a partner is during the interview.

How couples viewed and dealt with marital conflicts.

Oscillate between intense positive and negative emotions

Feel they have low control over the turbulence of their married lives

Feel like the difficulties in their marriage help them grow closer together.

To what degree the couple feels defeated and depressed about their marriage, and have given up on it.

\section{Conceptual parallels between marriage and employment}

Of course, marriage and employment are fundamentally different. Contrary to interpersonal relationships, employment typically involves formal aspects, such as a salary, and legal 
contracts. Employment is often seen as an agency that involves power inequality (Fox, 1974), and is not generally intended to last a lifetime. However, it is impossible to ignore evidence of similarities between the two kinds of relationships.

At their core, relationships are purposive (Fournier, 1998). Close interpersonal relationships offer several provisions to the individuals that engage in them (Duck, 2011): belonging and a sense of reliable alliance, opportunities for communication about ourselves, provision of assistance and physical support, reassurance of worth and value, opportunity to help others, and personality support. That is not to say that all relationships fully address each of these needs. It merely says that every relationships addresses, at least to some degree, at least some of these needs. This work argues that a person's workplace provides, to a degree that varies from person to person, and workplace to workplace, on most (if not all) of these accounts. For example, the construct "organisational identification” (Dutton, Dukerich, \& Harquail, 1994) captures the need for belonging and for reassurance of self-worth. The construct "perceived organisational support" captures to what extent the organisation addresses the need for reliance on another (Allen, Shore, \& Griffeth, 2003; Eisenberger, Huntington, Hutchison, \& Sowa, 1986). The need for personality support by associating with like-minded partners is captured by Person-Organisation fit (Kristof, 1996), and the need to help others is captured by inter-personal and organisational citizenship behaviour (Mossholder, et al., 2005; Organ, 1988; Podsakoff, MacKenzie, Paine, \& Bachrach, 2000). Relationships in the workplace have also been shown to provide opportunities for communication and support (Henderson \& Argyle 1985). Employees' expectation for support and assistance from their organisation has been extensively studied have been captured in studies of "psychological contract” (Cullinane \& Dundon, 2006; Rousseau \& Tijoriwala, 1998). Although an organisation is not a human being, we argue that it can be conceptualised as a partner in a relationship. People have been shown to have interpersonal relationships with partners that 
are not necessarily other human beings: pets (Hirschman, 1994), God or mortal status (Buber, 1946), and even consumer brands (Fournier, 1998). In such relationships, the non-human party is an active and contributing member of the relationship dyad.

In addition to the conceptual similarities, employment and marriage also share some dynamic features. Some behaviours which exist in partners of a marriage also exist in employment context, where the individual and their organisation are bonded in a mutually dependant relationship. For example, negativity has been identified as a problem in modern employment (Blau \& Andersson, 2005; Caldwell \& Liu, 2011; Sahdev, 2003). Uncivilised behaviour and disruptive communication have been identified as significant causes of turnover intentions and behaviour (Pearson, Andersson, \& Wegner, 2001). However, prediction of turnover based on these communication patterns has been within the range of other turnover predictors. The study by Pearson et al. therefore indicates that interactions are relevant to voluntary turnover on the one hand, and on the other hand that this relevance may not be sufficiently captured using self-reported survey methods. This conclusion makes the marital separation predictor both relevant to, and innovative in, organisational turnover research. Our study therefore seeks to examine the viability of viewing employment as an interpersonal relationship, and its potential for further insights on the subject of employee turnover.

There have been previous attempts to study the impact of interpersonal relationships within an organisation on staff turnover, for example: relationships with colleagues (Brunetto, FarrWharton, \& Shacklock, 2010; Golden, 2007; Hershcovis \& Barling, 2010; Tietze \& Nadin, 2011); with supervisors (Brunetto, et al., 2010; Dupré \& Day, 2007), and subordinates (Hershcovis \& Barling, 2010). These relationships have been found to influence retention, commitment, and performance. This study, however, examines the relationship with the organisation itself as a holistic relationship partner. 


\section{Adapting the divorce prediction method to turnover context}

Even when one accepts that an employment relationship can be seen as an interpersonal relationship, adapting Gottman's methods of divorce prediction to predict voluntary organisational turnover is not straightforward. Predicting divorce relies on the analysis of the interaction between the partners (Gottman, 1993; Gottman \& Krokoff, 1989). However, equivalent interactions between an individual and an organisation are difficult to define, since no one particular individual represents the entire organisation. Individuals have an important relationship with their supervisors (Brunetto, et al., 2010; Dupré \& Day, 2007), with their coworkers (Golden, 2007; Hershcovis \& Barling, 2010), with their subordinates (Harris, Kacmar, \& Witt, 2005), and with their customers (Hershcovis \& Barling, 2010). All of these relationships are found to influence their intentions towards, and behaviour of, turnover. In addition to their inter-personal relationships with individuals, employees also interact with groups within the organisation, which are perceived holistically, and not as a collection of separate individuals, for example: co-workers (Groysberg \& Lee, 2010), work-groups (Whiteoak, 2007), and management (Bélanger, Edwards, \& Wright, 2003). An organisation's interactions with employees through policies and processes has also been found to influence turnover intentions and behaviour (Allen, 2001; Kuvaas \& Dysvik, 2010; Ng \& Butts, 2009). These are all various aspects of the employment relationship - the relationship between the employee and the organisation as a whole. To maintain a holistic view of the organisation, as an entity with whom the employee interacts, direct interaction does not offer a suitable method of enquiry.

Unlike direct interactions, which may be difficult to apply to an organisational context, storytelling can be used to examine an individual's perspective on the interaction process. Storytelling is a recognised method for diagnosis and change of organisational issues (Denning, 2004, 2006). By modifying the marital instrument - the Oral History Interview 
method (OHI) - to work with individuals in an organisational context, rather than the joint spousal interview, the marital method has potential to create a similar analytical arrangement with increased potential for reliable indicators of voluntary turnover in the organisation.

This paper aims to examine the results from the method described above when it is applied to organisational settings. The next section describes this empirical activity, followed by a discussion of its results, and implications for the model.

\section{The method applied in an organisational context}

This empirical study applies the developed marital method in two organisational contexts, and seeks to answer the following questions:

The purpose of the study reported here is to identify and categorise the relational processes displayed by employees during the $\mathrm{OHI}$, and to compare these processes with the ones identified in marital research.

1. How well does the Oral History Interview method transfer into an organisational context, and how do its results compare with the results described in marital setting? Understanding this question will assist in adapting the method for effective use in predicting turnover in organisations.

2. What are the relational processes exhibited in an organisational setting that differentiate satisfied and dissatisfied workers, and what is their potential to predict voluntary turnover?

This research question works to confirm that the constructs revealed by the instrument are meaningful and have the potential to predict turnover. 


\section{Methodology}

A pilot study by the authors used the OHI with seven employees in a university in Israel (Alony, Hasan, \& Sense, 2014). The study identified all of the relational processes described in marital research (fondness, negativity, we-ness, expansiveness and mechanisms of dealing with conflict) in employee interviews. This study expands on the pilot by examining the input of more employees ( $\mathrm{N}=46)$, from different industries (legal and healthcare), of different tenure and roles.

For this purpose, the interview questions used in the Oral History Interview method in marital research (Buehlman, et al., 1992) were used to tease out participants' views of the organisation. Questions covered positive and negative events during the course of their employment, the organisations' strengths and weaknesses, and a view of a good and a bad workplace (see Table 2). Following the guidelines of interviewers in marital research (Buehlman, et al., 1992), the interviewer kept her input to a minimum, with rare occasional requests to elaborate or to clarify.

\section{TABLE 2}

OHI interview questions for employment context

\begin{tabular}{ll}
\hline $\begin{array}{l}\text { Beginning of the } \\
\text { relationship }\end{array}$ & $\begin{array}{l}\text { Can you tell me how you started working here? How was } \\
\text { your joining process? }\end{array}$ \\
\hline $\begin{array}{l}\text { Early days of the } \\
\text { relationship }\end{array}$ & How were your first days? What do you remember most? \\
\hline $\begin{array}{l}\text { Good recent } \\
\text { experience }\end{array}$ & $\begin{array}{l}\text { Can you tell me of something good that happened to you } \\
\text { here recently? }\end{array}$ \\
\hline $\begin{array}{l}\text { Bad recent } \\
\text { experience }\end{array}$ & $\begin{array}{l}\text { Most employees I talk to say work goes up and down. } \\
\text { Would you agree? Can you tell me of something not so } \\
\text { good that happened here recently? }\end{array}$ \\
\hline $\begin{array}{l}\text { Characteristics of a } \\
\text { good workplace }\end{array}$ & How would you describe a good [ward]/[firm] to work in? \\
$\begin{array}{l}\text { Characteristics of a } \\
\text { bad workplace }\end{array}$ & How would you describe a bad [ward]/[firm] to work in? \\
$\begin{array}{l}\text { Break } \\
\begin{array}{l}\text { Strengths of the } \\
\text { organisation }\end{array}\end{array}$ & What are your goals in doing this job? \\
$\begin{array}{l}\text { Weaknesses of the } \\
\text { organisation }\end{array}$ & What would you say are the weaknesses? \\
\hline
\end{tabular}




\section{Sample and data collection}

As part of a larger study, two organisations were involved: a law firm (LawFirm) and a healthcare provider (HealthyCare) in a large metropolitan city in Australia. Participants in this study had permanent positions (full- or part-time), and had been employed by their organisation for at least one year, to enable the formation of an employment relationship. Company tenure averaged seven years (range: one to thirty-five years at the time of the interview). Participant selection was random and not guided by potential satisfaction levels.

Eleven members from LawFirm and thirty-five members HealthyCare agreed to participate in this study, a total of forty-six participants. Out of these forty-six participants, four were highly trained clerical staff, nine lawyers and thirty-two nurses. Thirteen participants were males, and the rest were females. Twelve participants were in managerial roles - they would regularly oversee or supervise others.

Following the $\mathrm{OHI}$ approach, each participant was interviewed in a quiet room for as long as they took to respond to the interview questions - up to one hour. Since this research draws on the principles of storytelling, participants were instructed to freely discuss the topics that they thought were relevant. The interviews were voice-recorded and were analysed directly as sound-recordings using NVivo 9 (QSR International Pty Ltd, 2009). Interviews were then coded by identifying themes that are consistent with the indicators of relationship quality from the marital research.

\section{The OHI Coding system}

To analyse the interviews, the primary researcher reviewed the interview voice and video recordings, and coded their content in three major rounds. The first round focused on identifying relational processes; the second round focused on the relational process "we-ness" (versus separateness), and the third round aimed to capture positive and negative affect 
communicated by the participant. The second and third rounds were also used to refine the codes identified in the first round.

\section{First coding round: relational processes}

Relational processes were identified based on an a priori list, as described in section “Relational processes in marital research”: 1) fondness / affection towards organisation; 2) negativity towards organisation; 3) expansiveness versus withdrawal; 4) dealing with conflict; and 5) disappointment and disillusionment. Several other processes emerged as subcategories of this list, such as blame, dismissal, forgiveness, hope, diversion, proactiveness, delineation and reduction, and entitlement. Processes were identified based on verbal and nonverbal content.

\section{Second coding round- "we-ness" and separateness}

We-ness and separateness were coded as follows: every time the participant referred to their workplace as "we", the sentence was coded as part of "we-ness", and every time it was referred to as "they", that sentence was coded as "they-ness" (separateness). References to participants' job interviewers, subordinates and clients were not used for this calculation. References to management decisions by employees were calculated, because they indicate the degree to which participants feel aligned with management, and the degree they feel they have a say in managerial decisions.

The we-ness ratio was computed in a similar manner to the method used in Gottman (1994: 120), by dividing "they-ness" by the sum of "they-ness" and "we-ness" (that is, they/(we + they) ). The ratio communicates the same view as we/they; however, it solves the problem of dividing by zero, in case no "they" or "we" statements were used. 


\section{Third coding round - positive and negative affect}

The third round focused on identifying the affect underlying each message communicated by the participant, and used verbal, nonverbal and context to determine it. Inconclusive segments were marked by the coder, and accounted for $5.38 \%$ of the total interview time.

\section{Node aggregation}

Every relational process was set as a category of processes. Instances identified in each category were aggregated according to their content and context. For example, the category “negativity towards the organisation” resulted in over 80 nodes. Nodes which contained similar types of negativity (e.g., 'strong negativity', see below) were aggregated into one process type. After all aggregations were completed, the aggregated instances were reexamined to validate their aggregation. Some minor adjustments were made (less than $10 \%$ of the aggregations). Typical instances and their aggregated nodes are reported in the Results section next.

\section{Results}

This study shows that the indicative processes identified in the marital Oral History Interviews, which differentiated couples who are on a trajectory to divorce from couples who will remain married, can also be identified in an organisational context. Future research will examine if these processes can be used as indicators of the future trajectory of the employment relationship. The processes Fondness, Negativity, We-ness, Expansiveness, Disappointment, and Dealing with difficulty, which have been used to diagnose high- and low- quality relationship (Buehlman et al., 2005; Buehlman et al., 1992; Carrère, Ruckstuhl, Buehlman, Gottman, \& Coan, 2000; Gottman, Coan, Carrere, \& Swanson, 1998), were also identified in organisational context, and are described below. 
In addition, preliminary findings which indicate a relationship between turnover and the qualitative processes identified in this study are presented. The findings show that some processes were present (or absent) for employees who left their respective units within two years of the interview. The presence of these indicators in this new instrument - the Employment History Interview - suggests that this is a potentially valuable method that can be further developed and refined and which may ultimately provide reliable and accurate prediction of organisational turnover.

This study confirms the findings of the pilot study (Alony, et al., 2014), that all relational processes identified as predictors of the course of a marriage can be identified in employment context as well. However, contrary to the pilot study, this study found that the degrees of affect displayed by participants were similar, and not lower than, the affect described in marital research.

The following sections present the relational processes that were identified in employees' reflections on their past experiences during their employment. The processes, along with their sub-categories and examples, are illustrated in Tables 3, 4, 5, and 6. Quotes relevant to the processes are presented along with an indication of the sources. Instead of participants' names, the source is indicated with by the first letter of the participant's alias, and a number.

\section{Fondness or affection towards partner}

Various forms of fondness or affection were identified in this study. Participants provided positive views of their workplace in terms of past, present, or future. These positive views concerned various aspects in the organisation, as expected: the direct supervisor, colleagues, clients, subordinates, and the overall organisation. Virtually all participants expressed some degree of positive views of at least some parts of the organisation. The intensity of these positive views ranged from acknowledgment, through appreciation, up to excitement. 
Other forms of positive regards for the organisation were expressions of hope for improvement, empathy for the causers of a problem described, and a dynamic mechanism of directing the conversation to a positive testimony when asked about or describing a negative experience.

\section{TABLE 3}

Positive views of the organisation

\begin{tabular}{|c|c|}
\hline Past & "It had a nice family atmosphere” K3 \\
\hline Present & “They are very supportive of stuff like that" F1 \\
\hline Future & $\begin{array}{l}\text { "We're going through a very needed change, which will hopefully make } \\
\text { things better" A2 }\end{array}$ \\
\hline $\begin{array}{l}\text { Direct } \\
\text { supervisor }\end{array}$ & "Our direct manager is very approachable, you can always talk to her” E1 \\
\hline Colleagues & $\begin{array}{l}\text { "Some of the staff here advanced their qualifications - and that's good. } \\
\text { I'm happy for them.” I8; } \\
\text { "I like the staff here, we have a good mix. We get along quite well“ I7, }\end{array}$ \\
\hline Clients & $\begin{array}{l}\text { "Our patients are a lovely group to work with. They are usually really } \\
\text { sweet." L2 }\end{array}$ \\
\hline Subordinates & “I’m lucky I have such a good team” Q1 \\
\hline $\begin{array}{l}\text { General } \\
\text { organisation }\end{array}$ & "It is very family oriented, it gives you that flexibility you need" F1 \\
\hline
\end{tabular}

\section{Negativity towards partner}

Similarly to positive expressions towards the organisation, there were many forms of negative expressions towards the organisation. All participants expressed some sort of negativity towards their organisation. Many of these forms are similar to forms of negativity identified in marital research.

\section{TABLE 4}

Forms of negativity towards the organisation Justified criticism

Criticism of "Because of the numbers of patients we have to deal with, it is very processes in the hard to keep track of what's happening." L3

organisation "We now have to do bedside handover. It is problematic, because you cannot discuss everything freely in front of the patients. You have to maintain privacy, but other patients are there, and they can hear it. " E1

Criticism of "They go on much longer breaks than the rest of us. And then, when colleagues you need help with a patient and they are not there - and that happens every day, several times a day - that is not right” H6 
General criticism "Working short-staffed really takes its toll. Things get missed, you get of work

conditions exhausted, we get frustrated with one another - it's not a good thing”

\section{I7}

“We don’t have the equipment to do our job properly. They are simple things to fix" H7

Criticism of a “They know you're finished at 3:30, but they'll set up meetings for direct manager $\quad 4: 30$, and expect you to be there.”, R1

"I was out of my depth then, and I kept asking for help - but the support wasn't there.”, K2

Concern over the
effect of media
Concern over the
effects of short-
staff
Anxiety

"The media has had a terrible impact on patients and their families, having an idea of what happens on wards and in the hospital. They come here determined to make sure it doesn't happen to their loved ones - and that's fine, but I see nurses walk away crying - and that's not good. They take it that one step too far, to the point that we can't care for patients", E2

Concern over the "If you're short staffed, you're falling behind. And I don't mind 10 staff minutes behind, but 30-45 minutes, every time - that's a problem. Not because I want to get home, but because all of that stuff should already be prepared for the next shift. That's hard”, H3

Concern over "Last week we lost access to the main state's data base. That put a technology huge amount of pressure. The staff was very very stressed. Because dependence of a fault that we can't do anything about”, I3

\section{Restricted negativity}

Affective $\quad$ Being apologetic about mentioning it - I1

restriction forgiving the reasons $-\mathrm{H} 5$

Formality $\quad$ Using formal and non-judgmental language - K5, K3

restriction

Grief and sorrow "It's hard for me to deal with the impact on the family, when someone
passes away. “, J3

"I got pretty close with this patient, this 90 year old man, and then he passed away. And then no one lets you know - because you are noone to them, really, you don't go to the funeral, nothing.”, I2

Feeling taken for granted "They just assume that you will be there at 4:35 to respond to an email, and demand a response by close of business today, even though My shift ends at 3pm. There's this expectation that you'll stay back.”, R1

Isolation $\quad$ "I understand how busy it is on other wards, but I don't think they understand what it's like down here - how overloaded we are”, N1

Frustration "I found it frustrating - the old-school way of work here, and that the staff here thinks that it's ok”, B1

"We still have the odd few who wouldn't move on with the new way of doing things. That frustrates me a little bit. A lot.”, I7

Suffering "I am tracking the clock all day - is it time to go home yet?", L1

\begin{tabular}{ll}
\multicolumn{1}{c}{ Delivery mechanisms } \\
\hline $\begin{array}{l}\text { Delay or absence } \\
\text { of positives }\end{array}$ & "Things that have worked well?... ahm... ahm... sorry. No.”, A2 \\
$\begin{array}{l}\text { Negatives in a } \\
\text { positive story }\end{array}$ & "The initiative has one positive to it, but the way it is implemented is \\
not the best”, K5
\end{tabular}


"I suppose this new role helps, but things still take far too long. So it helps, but, there's still more to change”, L3

Ending a positive "Our strength is team work. Sometimes it's lacking, though.

story negatively Sometimes, it doesn't feel like we are a team at all”, I8

\begin{tabular}{|c|c|}
\hline & Strong negativity \\
\hline $\begin{array}{l}\text { Anger and } \\
\text { chastising }\end{array}$ & $\begin{array}{l}\text { "I don't think they want people on permanent positions - even though } \\
\text { they need them", H7 } \\
\text { "This attitude of -I'm just waiting to retire and you won't get anything } \\
\text { out of me- irritates me quite a lot”, I3 }\end{array}$ \\
\hline Demonising & $\begin{array}{l}\text { "That manager basically threw her to the wolves - scrap meat. That's } \\
\text { what she is to them”, L1 } \\
\text { "Management here - lots of lying, bullying, backstabbing.”, H1 }\end{array}$ \\
\hline Overwhelming & $\begin{array}{l}\text { “That's how we work here - our backs against the wall”, A3 } \\
\text { "We are so pushed here - it's overwhelming. That's the word - } \\
\text { overwhelming”. N1 }\end{array}$ \\
\hline Ridicule & $\begin{array}{l}\text { "Changes? They're always trying their little changes (sarcastically) - a } \\
\text { poster here, a table there.” } \\
\text { "The routines haven't changed at all for decades. And they've had } \\
\text { different managers during that time. Nothing's changed: 'this is how } \\
\text { we’ve always, this how we'll always do it'. Can't exactly fight that”, } \\
\text { I4 (emphasis original). }\end{array}$ \\
\hline
\end{tabular}

\section{Justified criticism}

Criticism was identified as a predictor of divorce, but it is unlikely to be a predictor of turnover because all participants, unexceptionally, expressed criticism of their workplace in one form or another.

Many participants expressed criticism that they elaborated on why it is justified ( $\mathrm{N}=20)$. This is usually accompanied by rational explanations and examples for their opinion. This processes was coded as “justified criticism”, to differentiate from general criticism of the organisation. Examples of this form include criticism of processes in the organisation, and criticism of colleagues. Most criticism was not directed at a particular cause, but more general criticism of work conditions.

\section{Anxiety}

Worries, concerns, and fear were expressed by some participants $(\mathrm{N}=8)$. Concerns were expressed for oneself, colleagues, and the general public. The common theme of the 
concerns expressed in this process is the concern over something that is far greater, and uncontrollable by the participant. Anxiety subjects identified were media, of the medical system, of developments in society, of dependence on technology, and of the effects on the workforce.

\section{Restrictive negativity}

Some participants restricted the negativity that they expressed in various ways $(\mathrm{N}=30)$ : affective ways (ending it with a smile, being apologetic about mentioning it, forgiving the reasons), some cognitive rational ways, by using formal, non-judgmental language.

\section{Pain}

Some participants expressed pain in various forms (N=15): grief and sorrow (N1, J3, L1, I2), feeling unappreciated (R1), feeling isolated from other parts of the organisation (N1), frustration (B1, U1, H4, J2, E2, I7), and suffering during work (L1).

\section{Negativity identified through delivery dynamics}

Some participants’ negativity was evident through the dynamics of their delivery $(\mathrm{N}=19)$ : they took a long time to express positives of the organisation or tell a positive story, they delivered positive stories in a negative feel, or they started off telling a positive story, and ended up focusing on the negatives.

\section{Strong negativity}

Forms of strong negativity were identified as negative processes that would not be typically accepted as an open expression in the work environment (anger and chastising), negativity that transcends professional boundaries (demonising), expressions of feeling overwhelmed (similar to flooding in divorce), negativity expressed with definitive language, helplessness, pessimism, and ridicule - as contempt was identified as a predictor of divorce. About a half of all participants expressed some form of strong negativity $(\mathrm{N}=21)$. 


\section{We-ness versus separateness}

The usage of the expressions "we" and "they" to describe the firm in various contexts was coded. Two distinct forms of we-ness they-ness were identified and aggregated: using “we” in general, as opposed to using "we" to identify with a specific sub-group (ward, team, profession, role, location), as well as using “they” in general to refer to the organisation, or s specific "they" to refer to a specific sub-group which they do not belong to - subordinates, managers or seniors, junior staff, people of a different role, etc.

One participant was not coded for any used of "we-ness". Five participants only used "they" in the context of a subgroup which they do not belong to, and three of them were in managerial positions.

\section{Expansiveness versus withdrawal}

One form of withdrawal identified in this study was coded as 'avoiding discussion' $(\mathrm{N}=5)$, and included avoidance of discussing matters of conflict: providing short and deflecting answers, refusing to elaborate on the conflict. Other forms identified include a continuous need for prompting throughout the interview $(\mathrm{N}=12)$.

\section{Disappointment and disillusionment}

Some participants $(\mathrm{N}=9)$ expressed disappointment and disillusion. Participants either expressed disappointment in their superiors or a general disappointment in their workplace

\section{TABLE 5}

Disappointment and disillusion

Disappointment "They say that they will consult us before they implement a change, but in management they don't. They say they'll ask us for feedback, but they don't. When we raise an issue, they say - 'you just don't like change'”, H1 "Their actions show that they don't understand what it's like to actually work here”, K6;

"They focus on the wrong things. They don't care about people anymore, just about cutting costs”, L1 
General disappointment
"When I started I thought things here were better, but then I realised that it's all the same. It's no different to where I've just left”, H4;

"It was supposed to get easier and better with time, but it never really happened for me” G1.

\section{Dealing with conflict}

Several mechanisms were used by participants when they described difficult events in the organisation, and they do not map perfectly onto the processes identified in marital research. Three main processes are described here: considering the positives, avoiding discussion, and glorifying (or accepting) the struggle.

\section{TABLE 6}

Mechanisms for dealing with conflicts Considering the positives

Appreciating "People here can be racist towards me, but from my point of view, it positives taught me to be more assertive. I'm a lot more assertive now”, I8 "My start here was very hard, but I had fantastic support from my staff”, I3

Balancing against "It's very hard to work here - but it's not worth moving. I like this a strength place, and if you weigh it all up - pros and cons - it's not worth it", $\mathrm{H} 4$

"I'm studying as well as working, and I'm very well supported in that. I don't know that I'd get that kind of support somewhere else”, J4 "We were backed into a corner, and that made us come up with alternatives, which in the end worked out not too bad, and we still use them today", K5

Acknowledging "We've discussed that with our supervisor and came up with an resolution advocacy process, which means we can now voice our objections in a structured, and acceptable way”, I2

"They used to ask me to do things that are outside my role description. Since then, the patient-to-staff ratios have changed here, so that improved things a lot, and the manager also knocked things right on the head, so things like that do not happen again”, K4

\begin{tabular}{ll}
\hline & \multicolumn{1}{c}{ Avoid discussion } \\
\hline $\begin{array}{l}\text { Accepting faults } \\
\text { No adverse effect }\end{array}$ & $\begin{array}{l}\text { "That should not have happened. But hindsight is always easy”, K3 } \\
\text { - that didn't matter anyway", J2 } \\
\text { "I spoke up about it and they moved things back to how they should } \\
\text { be, and that was it”, Y2 }\end{array}$ \\
\hline \multicolumn{1}{c}{ Glorifying and accepting the struggle } \\
$\begin{array}{l}\text { Explicit } \\
\begin{array}{l}\text { gcceptance } \\
\text { through }\end{array}\end{array}$ & $\begin{array}{l}\text { "I like challenges. This job was a huge challenge for me to address" I3 } \\
\text { "The patients don't choose to be here on weekends - they have to be }\end{array}$
\end{tabular}


empathy

Hardships as "That's the way it is in this industry" E2;

part pf reality "That's just life - it's never perfect" H6

"Things like that happen on every ward" J1

"There's always elements of the job you won't like” J2

Acceptance as "That's the focus now - more on academic education than on practical

part of change in experience.” $\mathrm{H} 6$

times

Accepting "That's how it is when you are new to a workplace like this" H2

objective "We might think that it's the wrong thing to do, but sometimes it works

hardships out for the best, and that's wonderful” I2,

\section{Considering positives}

Some participants $(\mathrm{N}=20)$ identified positive points after describing a conflict or a difficult

event in their employment. They either appreciated positive elements in the organisation, balanced the difficulty described against a strength, or pointed out that the difficulty has been resolved.

\section{Avoiding discussion of difficulties}

Some participants $(\mathrm{N}=5)$ described a difficulty or a conflict between them and the organisation, but after the description they made short dismissive statements and withdrew from the topic. Their dismissive statements referred to the absence of adverse effects, or to an acceptable fault.

\section{Glorifying struggles}

Participants rarely glorified their struggles explicitly. Some ( $\mathrm{N}=23)$, however, expressed a genuine acceptance of difficulties, as part of reality. This acceptance of the hardships is driven from either empathy for those causing the hardship), acceptance that those causes of hardship are unavoidable), acceptance that times have changed), acceptance that the situation objectively involves hardships 


\section{Relation to employee turnover}

Some indicators of a relationship between the relational processes identified and actual turnover were found, despite the relatively short follow-up time. Six participants have left their respective units ${ }^{1}$ after a 2 year follow-up, which makes statistical testing difficult. A ttest comparing those who have left with those who remained in their respective units revealed that those who left did not display the following processes: positives from a negative, considering the positives in a conflict, or avoid discussion. The results are summarised in Table 7. These results are further strengthened by further data, not presented in this paper, which will be discussed in future publications.

\section{TABLE 7}

Processes significantly related to turnover

\begin{tabular}{llllllll}
\hline & & $\mathrm{N}$ & Mean & $\begin{array}{c}\text { Std. } \\
\text { Deviation }\end{array}$ & $\begin{array}{c}\text { Std. Error } \\
\text { Mean }\end{array}$ & Sig $^{2}$ \\
\hline Positives from a negative & Left & 6 & 0.000 & 0.000 & 0.000 & \\
& Stayed & 39 & .2564 & .442 & .0708 & $.001^{* *}$ \\
Avoided discussing difficulties & Left & 6 & 0.000 & 0.000 & 0.000 & \\
& Stayed & 39 & .1282 & .339 & .0542 & $.023^{*}$ \\
Considered positives & Left & 6 & 0.000 & 0.000 & 0.000 & \\
& Stayed & 39 & .487 & .506 & .0811 & $.000^{* *}$ \\
\hline$* * p<.01 ; * p<.05$ & & & & & & \\
\hline
\end{tabular}

\section{Discussion}

Three main points arise from the results: (1) the applicability of the marital Oral History Interview to organisational research, (2) the intensity of affect displayed by participants, and (3) the value of diagnosing the employment relationship for turnover prediction.

\footnotetext{
${ }^{1}$ Notably, some employees left reluctantly, due to personal circumstances.

2 2-tailed, equal variance not assumed.
} 


\section{Applicability of martial research method}

These findings indicate that the Oral History Interview method can be adapted for use in studying employment relationships, with the aim of providing an accurate method of predicting turnover. After adjustment, the questions led employees to generate affect-laden stories about their employment history. These stories contain several indicators that have been used in marital research to distinguish between distressed and non-distressed couples. Employees expressed fondness of affection towards their organisation, various forms of negativity towards various aspects in their organisations, and disappointment and disillusion with their organisation or with their work, similarly to spouses who discuss their marriage. Some employees exhibited withdrawal from discussing difficulties related to their work in their organisation, similarly to spouses exhibiting withdrawal from discussing their marriage. This finding indicates the interpersonal relationships share characteristics with personorganisation relationships, and thus expands the scope of interpersonal relationships.

\section{Intensity of affectivity displayed}

Contrary to the pilot study (Alony, et al., 2014), the levels of affect identified in this study were not dissimilar from the levels of affect described in marital research. The differences may be due to the different professions selected (lawyers and nurses as opposed to academics in the pilot study), a wider range of tenure (from one to over 30 years as opposed to between ten and 20 years in the pilot study), and a wider range of satisfaction and dissatisfaction levels. The similarity in affect levels identified in this study and the affect levels described in marital research indicates two main points. First, it indicates that an employment relationship is not less affect-laden than a marital relationship, despite involving more pragmatic and calculated aspects. The intensities of affect identified, both positive and negative, indicate that employment experiences create memories that rich in affective content. 
Second, the method of data collection (individual interview as opposed to a couples' interview) is suitable to evoke affective reactions. Unlike the pilot study, the questions in this study (which sought a direct input about the organisations' strengths and weaknesses) and the range of employee satisfaction levels resulted in a range of affective intensity that is similar to marital research. Both positive and negative emotions were displayed with intensity ranging from indifference to passionate.

\section{Predicting employee turnover}

Preliminary results show that some of the processes identified in the employment context significantly correlated with employee turnover. Consistently with marital research, employees who considered the positives and who changed the conversation from negatives to positives did not turnover. However, one process seems to differ in employment context and in marital research. Individuals who avoided discussing a difficult experience seem to display a process similar to withdrawal. This process predicted divorces in marital research, whereas in this study, the absence of this process was significantly associated with turnover. A potential explanation for this difference is that in a work context, this mechanism of avoiding difficult memories serves to sustain a relationship - for some individuals.

Future research will determine if these indicators predict the course of the relationship between the employees and the organisation, as the presence of these indicators suggests an interesting direction for enquiry. A wider sample of industries, tenure, and roles in follow-up studies will provide further understanding of the applicability of this method to organisational research.

\section{Conclusion}

The prediction of organisational employee turnover remains a problematic area with low reliability. The paper argues that earlier models are lacking due to their inability to properly 
acknowledge and measure the employment relationship. They thereby fail to provide real value. This paper presents a model which has been developed and proven to predict marital separation with high accuracy. This model was then tested in organisational settings after being adapted to the employment context. This study concludes that the tool used for diagnosing marital relationships is viable in organisational settings, and that the relational processes identified in organisational settings have some similarities to those identified in marital setting. The study also shows that some of these processes are related to future employee turnover. The outcome of this research and theoretical development is an instrument that has the potential to improve prediction models in the area of organisational turnover. Furthermore, this study expands the notion of interpersonal relationships to include abstract and non-human relationships as possible partners for a human relationship.

This ground-breaking study can be further advanced through similar additional longitudinal empirical studies involving a larger and more diverse group of participants, and also involve a follow-up measure of turnover, as well as measures of organisational and work-related attitudes. 


\section{References}

Albion, M. J., Fogarty, G. J., Machin, M. A., \& Patrick, J. (2008). Predicting absenteeism and turnover intentions in the health professions. Australian Health Review, 32(2), 271-281.

Allen, D. G., Renn, R. W., Moffitt, K. R., \& Vardaman, J. M. (2007). Risky business: The role of risk in voluntary turnover decisions. Human Resource Management Review, 17(3), 305-318.

Allen, D. G., Shore, L. M., \& Griffeth, R. W. (2003). The Role of Perceived Organizational Support and Supportive Human Resource Practices in the Turnover Process. Journal of Management, 29(1), 99-118. doi: 10.1177/014920630302900107

Allen, T. D. (2001). Family-supportive work environments: The role of organizational perceptions. Journal of Vocational Behavior, 58(3), 414-435.

Alony, I., Hasan, H., \& Sense, A. (2014). Predicting turnover based on relationship diagnosis - Lessons from marital research. Paper presented at the Proceedings of Informing Science \& IT Education Conference (InSITE) Wollongong, Australia.

Arnold, H. J., Feldman, D. C., \& Purbhoo, M. (1985). The role of social-desirability response bias in turnover research. Academy of Management Journal, 28(4), 955-966.

Bélanger, J., Edwards, P. K., \& Wright, M. (2003). Commitment at Work and Independence From Management A Study of Advanced Teamwork. Work and Occupations, 30(2), 234-252.

Benson, G. S. (2006). Employee development, commitment and intention to turnover: a test of 'employability' policies in action. Human Resource Management Journal, 16(2), 173-192. doi: 10.1111/j.1748-8583.2006.00011.x

Blau, G., \& Andersson, L. (2005). Testing a measure of instigated workplace incivility. Journal of Occupational and Organizational Psychology, 78(4), 595-614.

Bradbury, T. N., \& Fincham, F. D. (1987). Affect and cognition in close relationships: Towards an integrative model. Cognition and emotion, 1(1), 59-87.

Brunetto, Y., Farr-Wharton, R., \& Shacklock, K. (2010). The impact of supervisor-subordinate relationships on morale: implications for public and private sector nurses' commitment. Human Resource Management Journal, 20(2), 206-225. doi: 10.1111/j.17488583.2009.00117.x

Brunetto, Y., Teo, S. T. T., Shacklock, K., \& Farr-Wharton, R. (2012). Emotional intelligence, job satisfaction, well-being and engagement: explaining organisational commitment and turnover intentions in policing. Human Resource Management Journal, 22(4), 428-441. doi: 10.1111/j.1748-8583.2012.00198.x

Buber, M. (1946). Essays in Religion: London: Oxford University Press.

Buehlman, K., Carrere, S., \& Siler, C. (2005). The oral history coding system: A measure of marital cognition. In V. L. Manusov (Ed.), The sourcebook of nonverbal measures: Going beyond words (pp. 200-209). New Jersey: Taylor \& Francis.

Buehlman, K. T., Gottman, J. M., \& Katz, L. F. (1992). How a couple views their past predicts their future: Predicting divorce from an oral history interview. Journal of Family Psychology, 5(34), 295-318.

Caldwell, S. D., \& Liu, Y. (2011). Further investigating the influence of personality in employee response to organisational change: the moderating role of change-related factors. Human Resource Management Journal, 21(1), 74-89. doi: 10.1111/j.1748-8583.2010.00127.x

Carrère, S., Ruckstuhl, L., Buehlman, K. T., Gottman, J. M., \& Coan, J. A. (2000). Predicting Marital Stability and Divorce in Newlywed Couples. Journal of Family Psychology, 14(1), 42-58.

Cullinane, N., \& Dundon, T. (2006). The psychological contract: a critical review. International Journal of Management Reviews, 8(2), 113-129.

Denning, S. (2004). Telling tales. harvard business review, 82(5), 122-129.

Denning, S. (2006). Effective storytelling: strategic business narrative techniques. Strategy \& Leadership, 34(1), 42-48. 
Dess, G. G., \& Jason, D. S. (2001). Voluntary Turnover, Social Capital, and Organizational Performance. The Academy of Management Review, 26(3), 446-456. doi: 10.2307/259187

Doty, D. H., \& Glick, W. H. (1998). Common Methods Bias: Does Common Methods Variance Really Bias Results? Organizational Research Methods, 1(4), 374-406. doi: 10.1177/109442819814002

Duck, S. (2011). Rethinking relationships: SAGE Publications, Incorporated.

Dupré, K. E., \& Day, A. L. (2007). The effects of supportive management and job quality on the turnover intentions and health of military personnel. Human Resource Management, 46(2), 185-201. doi: 10.1002/hrm.20156

Dutton, J. E., Dukerich, J. M., \& Harquail, C. V. (1994). Organizational images and member identification. Administrative Science Quarterly, 39(2), 239-263.

Dysvik, A., \& Kuvaas, B. (2010). Exploring the relative and combined influence of mastery-approach goals and work intrinsic motivation on employee turnover intention. Personnel Review, 39(5), 622-638.

Eisenberger, R., Huntington, R., Hutchison, S., \& Sowa, D. (1986). Perceived organizational support. Journal of applied psychology, 71(3), 500-507.

Fang, T. (2009). Workplace responses to vacancies and skill shortages in Canada. International Journal of Manpower, 30(4), 326-348.

Fincham, F., \& Bradbury, T. (1990). Cognition in Marriage The Psychology of marriage: basic issues and applications (pp. 118-149): The Guilford Press.

Fournier, S. (1998). Consumers and their brands: Developing relationship theory in consumer research. Journal of consumer research, 24(4), 343-373.

Fox, A. (1974). Beyond contract: Work, power and trust relations: Faber London.

Golden, T. (2007). Co-workers who telework and the impact on those in the office: Understanding the implications of virtual work for co-worker satisfaction and turnover intentions. Human Relations, 60(11), 1641-1667. doi: 10.1177/0018726707084303

Gottman, J. M. (1993). A theory of marital dissolution and stability. Journal of Family Psychology, 7(1), 57-75.

Gottman, J. M. (1994). What Predicts Divorce? The Relationship Between Marital Processes and Marital Outcomes. Hilsdale, New Jersey: Lawrence Erlbaum.

Gottman, J. M. (1999). The marriage clinic: A scientifically-based marital therapy: WW Norton \& Company.

Gottman, J. M., Coan, J., Carrere, S., \& Swanson, C. (1998). Predicting marital happiness and stability from newlywed interactions. Journal of Marriage and Family, 60(1), 5-22.

Gottman, J. M., \& Krokoff, L. J. (1989). Marital interaction and satisfaction: A longitudinal view. Journal of Consulting and Clinical Psychology, 57(1), 47-52.

Gottman, J. M., \& Notarius, C. I. (2000). Decade review: Observing marital interaction. Journal of Marriage and Family, 62(4), 927-947.

Gottman, J. M., \& Notarius, C. I. (2002). Marital research in the 20th century and a research agenda for the 21st century. Family Process, 41(2), 159-197.

Griffeth, R. W., \& Hom, P. W. (2001). Retaining valued employees: Sage Publications, Inc.

Griffeth, R. W., Hom, P. W., \& Gaertner, S. (2000). A meta-analysis of antecedents and correlates of employee turnover: Update, moderator tests, and research implications for the next millennium. Journal of Management, 26(3), 463-488.

Groysberg, B., \& Lee, L.-E. (2010). Star power: colleague quality and turnover. Industrial and Corporate Change, 19(3), 741-765. doi: 10.1093/icc/dtp049

Harris, K. J., Kacmar, K. M., \& Witt, L. (2005). An examination of the curvilinear relationship between leader-member exchange and intent to turnover. Journal of Organizational Behavior, 26(4), 363-378. 
Hershcovis, M. S., \& Barling, J. (2010). Towards a multi-foci approach to workplace aggression: A meta-analytic review of outcomes from different perpetrators. Journal of Organizational Behavior, 31(1), 24-44. doi: 10.1002/job.621

Hicks, M. W., McWey, L. M., Benson, K. E., \& West, S. H. (2004). Using what premarital couples already know to inform marriage education: Integration of a Gottman model perspective. Contemporary Family Therapy, 26(1), 97-113.

Hirschman, E. C. (1994). Consumers and their animal companions. Journal of consumer research, 616-632.

Hom, P. W., \& Griffeth, R. W. (1995). Employee turnover. Cincinnati, OH: South-Western.

Jacobs, E. J., \& Roodt, G. (2011). The mediating effect of knowledge sharing between organisational culture and turnover intentions of professional nurses. SA Journal of Information Management, 13(1), 6 pages.

Khatri, N., Fern, C. T., \& Budhwar, P. (2001). Explaining employee turnover in an Asian context. Human Resource Management Journal, 11(1), 54-74. doi: 10.1111/j.17488583.2001.tb00032.x

Knox, A., \& Walsh, J. (2005). Organisational flexibility and HRM in the hotel industry: evidence from Australia. Human Resource Management Journal, 15(1), 57-75. doi: 10.1111/j.17488583.2005.tb00140.x

Kristof, A. L. (1996). Person-organization fit: An integrative review of its conceptualizations, measurement, and implications. Personnel Psychology, 49(1), 1.

Kuvaas, B., \& Dysvik, A. (2010). Does best practice HRM only work for intrinsically motivated employees? The International Journal of Human Resource Management, 21(13), 2339-2357.

Lee, G. J., \& Rwigema, H. (2005). Mobley revisited: dynamism in the process of employee

turnover. The International Journal of Human Resource Management, 16(9), 1671-1690.

Loan-Clarke, J., Arnold, J., Coombs, C., Hartley, R., \& Bosley, S. (2010). Retention, turnover and return - a longitudinal study of allied health professionals in Britain. Human Resource Management Journal, 20(4), 391-406. doi: 10.1111/j.1748-8583.2010.00140.x

Maertz, C. P. (2004). Eight motivational forces and voluntary turnover: A theoretical synthesis with implications for research. Journal of Management, 30(5), 667-683.

Mano-Negrin, R., \& Kirschenbaum, A. (1999). Push and pull factors in medical employees' turnover decisions: the effect of a careerist approach and organizational benefits on the decision to leave the job. The International Journal of Human Resource Management, 10(4), 689-702.

McHugh, M. D., Kutney-Lee, A., Cimiotti, J. P., Sloane, D. M., \& Aiken, L. H. (2011). Nurses' Widespread Job Dissatisfaction, Burnout, And Frustration With Health Benefits Signal Problems For Patient Care. Health Affairs, 30(2), 202-210.

Milbourn, G. (2012). Job Stress and Job Dissatisfaction: Meaning, Measurement and Reduction - A Teaching Note. Journal of American Academy of Business, Cambridge, 18(1), 1-9.

Morrell, K., Loan-Clarke, J., Arnold, J., \& Wilkinson, A. (2007). Mapping the decision to quit: a refinement and test of the unfolding model of voluntary turnover. Applied Psychology, 57(1), 128-150.

Mossholder, K. W., Settoon, R. P., \& Henagan, S. C. (2005). A relational perspective on turnover: Examining structural, attitudinal, and behavioral predictors. Academy of Management Journal, 48(4), 607-618.

Mowday, R. T. (1984). Strategies for adapting to high rates of employee turnover. Human Resource Management, 23(4), 365-380.

Ng, T. W., \& Butts, M. M. (2009). Effectiveness of organizational efforts to lower turnover intentions: The moderating role of employee locus of control. Human Resource Management, 48(2), 289-310.

Nyberg, A. (2010). Retaining your high performers: Moderators of the performance-job satisfactionvoluntary turnover relationship. Journal of applied psychology, 95(3), 440. 
Organ, D. W. (1988). Organizational citizenship behavior: The good soldier syndrome: Lexington Books/DC Heath and Com.

Pearson, C. M., Andersson, L. M., \& Wegner, J. W. (2001). When workers flout convention: A study of workplace incivility. Human Relations, 54(11), 1387-1419

Podsakoff, P. M., MacKenzie, S. B., Lee, J. Y., \& Podsakoff, N. P. (2003). Common method biases in behavioral research: A critical review of the literature and recommended remedies. Journal of applied psychology, 88(5), 879-903.

Podsakoff, P. M., MacKenzie, S. B., Paine, J. B., \& Bachrach, D. G. (2000). Organizational citizenship behaviors: A critical review of the theoretical and empirical literature and suggestions for future research. Journal of Management, 26(3), 513-563.

QSR International Pty Ltd. (2009). QSR NVivo 9 (Version 9.0). Retrieved from www.qsrinternational.com.

Reiche, B. S. (2009). To quit or not to quit: organizational determinants of voluntary turnover in MNC subsidiaries in Singapore. The International Journal of Human Resource Management, 20(6), $1362-1380$.

Rousseau, D. M., \& Tijoriwala, S. A. (1998). Assessing psychological contracts: Issues, alternatives and measures. Journal of Organizational Behavior, 19(S1), 679-695.

Sahdev, K. (2003). Survivors' reactions to downsizing: the importance of contextual factors. Human Resource Management Journal, 13(4), 56-74. doi: 10.1111/j.1748-8583.2003.tb00105.x

Sias, P. M., Heath, R. G., Perry, T., Silva, D., \& Fix, B. (2004). Narratives of workplace friendship deterioration. Journal of Social and Personal Relationships, 21(3), 321-340.

Smith, D. R., Holtom, B. C., \& Mitchell, T. R. (2011). Enhancing precision in the prediction of voluntary turnover and retirement. Journal of Vocational Behavior, 79(1), 290-302.

Sonnentag, S. (2003). Recovery, work engagement, and proactive behavior: a new look at the interface between nonwork and work. Journal of applied psychology, 88(3), 518.

Steel, R. P., \& Lounsbury, J. W. (2009). Turnover process models: review and synthesis of a conceptual literature. Human Resource Management Review, 19(4), 271-282.

Swider, B. W., Boswell, W. R., \& Zimmerman, R. D. (2011). Examining the job search-turnover relationship: The role of embeddedness, job satisfaction, and available alternatives. Journal of applied psychology, 96(2), 432.

Tietze, S., \& Nadin, S. (2011). The psychological contract and the transition from office-based to home-based work. Human Resource Management Journal, 21(3), 318-334. doi: 10.1111/j.1748-8583.2010.00137.x

Vaiman, V. (2008). Retention management as a means of protecting tacit knowledge in an organisation: a conceptual framework for professional services firms. International Journal of Learning and Intellectual Capital, 5(2), 172-185.

Weisberg, J., \& Kirschenbaum, A. (1991). Employee turnover intentions. The International Journal of Human Resource Management, 2(3), 359-375.

Weiss, R. L. (Ed.). (1980). Strategic behavioral marital therapy: Toward a model for assessment and intervention (Vol. 1): Jai Press Greenwich, CT.

Whiteoak, J. W. (2007). The relationship among group process perceptions, goal commitment and turnover intention in small committee groups. Journal of Business and Psychology, 22(1), 1120.

Winterton, J. (2004). A conceptual model of labour turnover and retention. Human Resource Development International, 7(3), 371-390.

Wöcke, A., \& Heymann, M. (2012). Impact of demographic variables on voluntary labour turnover in South Africa. The International Journal of Human Resource Management, 23(16), 3479-3494.

Yanadori, Y., \& Kato, T. (2007). Average employee tenure, voluntary turnover ratio, and labour productivity: evidence from Japanese firms. The International Journal of Human Resource Management, 18(10), 1841-1857. 